\title{
What is a Reasonable Screening Test for Colorectal Cancer
}

\author{
Young Jin Kim \\ Department of Surgery, Chonnam National University Medical School, Gwangju, Korea
}

\section{See Article on Page 420-423}

The methods of screening tests are stool examinations, such as the fecal occult blood test (FOBT) and the fecal DNA test, and evaluations of images, such as flexible sigmoidoscopy, colonoscopy, double-contrast barium enema and computed tomographic colonography. The advantages and the disadvantages of different screening tests have been the subject of intense debate. An accurate screening test would have high sensitivity when an adenomatous polyp or cancer is present and high specificity in their absence. Randomized controlled trials using the FOBT as the screening strategy have shown a reduction in mortality due to colorectal cancer. The fecal DNA panel (k-ras, APC, p53 and BAT-26) was more sensitive than the FOBT for invasive cancer and adenomas, but its cost effectiveness is controversial [1]. Colonoscopy has theoretical advantages over other screening tests, including direct visualization of the entire colon and, more importantly, removal of precancerous adenomatous lesions. Colonoscopy has averted the greatest number of deaths from colorectal cancer $(31 \%)$, followed by annual fecal occult blood testing (29\%), flexible sigmoidoscopy (21\%) and biennial fecal occult blood testing (19\%) [2,3]. The FOBT was preferred as a screening test by $70.2 \%$ of the participants and colonoscopy by 9.3\% because colonoscopy was significantly more time consuming, was disturbing, painful, and annoying, and involved risks [4]. In conclusion, screening based on stool tests with colonoscopic follow-up of positive test results might offer a high potential for early detection or prevention of colorectal cancer.
Correspondence to: Young Jin Kim, M.D.

Department of Surgery, Chonnam National University Hospital, 8 Hak-dong, Dong-gu, Gwangju 501-757, Korea

Tel: +82-62-220-5001, Fax: +82-62-225-7448

E-mail:kimyjin@chonnam.ac.kr

(C) 2010 The Korean Society of Coloproctology

This is an open-access article distributed under the terms of the Creative Commons Attribution NonCommercial License (http://creativecommons.org/licenses/by-nc/3.0) which permits unrestricted noncommercial use, distribution, and reproduction in any medium, provided the original work is properly cited.

\section{REFERENCES}

1. Capella G. Is fecal DNA testing superior to fecal occult-blood testing for colorectal cancer screening? Nat Clin Pract Oncol 2005;2:234-5.

2. O'Leary BA, Olynyk JK, Neville AM, Platell CF. Cost-effectiveness of colorectal cancer screening: comparison of communitybased flexible sigmoidoscopy with fecal occult blood testing and colonoscopy. J Gastroenterol Hepatol 2004;19:38-47.

3. Haug U, Brenner H. A simulation model for colorectal cancer screening: potential of stool tests with various performance characteristics compared with screening colonoscopy. Cancer Epidemiol Biomarkers Prev 2005;14:422-8.

4. Almog R, Ezra G, Lavi I, Rennert G, Hagoel L. The public prefers fecal occult blood test over colonoscopy for colorectal cancer screening. Eur J Cancer Prev 2008;17:430-7. 